Territorios 37 / Bogotá, 2017, pp. 17-40

ISSN: 0123-8418

ISSNe: 2215-7484

Ciudades y conflictos en América Latina: ayer, hoy, mañana (II)

\title{
Capitalismo, refundación y conflicto. La disputa por el espacio-tiempo urbano en Córdoba, Argentina
}

Capitalism, Refoundation and Conflict. The Dispute for Urban Space-time in Cordoba, Argentina

Capitalismo, refundação e conflito. A disputa pelo espaço-tempo urbano em Córdoba, Argentina

\author{
Cecilia Michelazzo* \\ Katrina Salguero Myers ${ }^{\star *}$
}

Recibido: 30 de abril de 2016

Aprobado: 12 de abril de 2017

Doi: http://dx.doi.org/10.12804/revistas.urosario.edu.co/territorios/a.4833

Para citar este artículo:

Michelazzo, C., \& Salguero, K. (2017). Capitalismo, refundación y conflicto. La disputa por el espacio-tiempo urbano en Córdoba, Argentina. Territorios, (37), 17-40. Doi: http://dx.doi.org/10.12804/revistas.urosario. edu.co/territorios/a. 4833

* Licenciada en Comunicación Social, doctoranda con mención en Ciencias Sociales y Humanas. Integrante del programa de Ideologia y Prácticas Sociales en Conflicto del Centro de Investigaciones y Estudios sobre Cultura y Sociedad (CIECS) de la Universidad Nacional de Córdoba y el CONICET. Docente de la Facultad de Ciencias de la Comunicación, Universidad $\mathrm{Na}$ cional de Córdoba. Áreas de estudios: juventudes, segregación urbana, sensibilidades sociales, acción colectiva, conflicto social. Correo electrónico: ceciliamichelazzo@hotmail.com ORCID: http://orcid. org/0000-0001-5624-9786

* Licenciada en Comunicación Social, maestranda en Comunicación 
Palabras clave

Segregación, clases sociales, conflicto, ordenamiento urbano, experiencias sociales.

Keywords

Segregation, social class, conflict, urban order, social experiences.

Palavras-chave

Segregação, classes sociais, conflito, ordenamento urbano, experiências sociais.

\section{tersitarias 37}

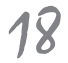

\section{RESUMEN}

En el presente artículo analizaremos las dinámicas de la disputa por el espacio-tiempo urbano en la ciudad de Córdoba, Argentina. Para ello estudiamos el caso de dos barrios lindantes con la zona céntrica de la ciudad: Alberdi y San Vicente. Unidos ambos por ser lugares históricos, con diversidad étnica, social y económica; estos territorios están actualmente en una disputa por la definición de las modalidades y actores que pueden vivir en ellos.

En el vasto campo de estudios urbanos, hemos situado nuestros intereses e interrogantes en las maneras en que Córdoba ha sido modificada por la convergencia de políticas públicas e intervenciones privadas que reordenan el espacio en sentido clasista.

Analizaremos, así, los procesos de refundación temporal y espacial de estos barrios que los actores "desarrollistas" y empresariales han iniciado, en convergencia con las políticas públicas y los conflictos que se desenvuelven con los habitantes que intentan defender un modo de vida en el territorio.

Pretendemos preguntarnos por las lógicas de reproducción del capital en las ciudades periféricas y por las dimensiones materiales, significantes y sensibles que estructuran las experiencias sociales posibles.

\section{ABSTRACT}

In this article we will analyze the dynamics of the dispute that takes place for urban spacetime, in the city of Cordoba, Argentina. For such a goal we will study the case of two neighborhoods that border the downtown area of the city: Alberdi and San Vicente. Tied to each other for having a similar history, holding antique buildings, and for their ethnic, social and economic diversity; these territories are currently in dispute regarding the definitions of the ways and actors that can live in them.

In the vast field of urban studies, we have placed our interest and interrogations in the ways that Cordoba has been modified by the convergence of public policies and private actions that commands space in a class separation direction.

We will analyze the processes of time and space refoundation in these neighborhoods, started by "urban developers" and corporate actors, in convergence with public policies, carrying conflicts with the inhabitants that try to defend a certain way of life in the territory.

We examine the logics of capital in peripheral cities, and the material, signifying and sensible dimensions that structure possible social experiences.

\section{RESUMO}

No presente artigo analisaremos as dinâmicas da disputa pelo espaço/tempo urbano na cidade de Córdoba, Argentina. Para isto estudamos o caso de dois bairros limitantes com a zona central da cidade: Alberdi e San Vicente. Unidos ambos os dois por ser lugares históricos, com diversidade étnica, social e econômica; estes territórios estão atualmente em uma disputa pela definição das modalidades e atores que podem viver neles. 
No vasto campo de estudos urbanos, temos situado os nossos interesses e interrogantes nas maneiras em que Córdoba tem sido modificada pela convergência de políticas públicas e intervenções privadas que reordenam o espaço em sentido classista.

Analisaremos assim, os processos de refundação temporal e espacial destes bairros que os atores "desenvolvimentistas" e empresariais têm iniciado, em convergência com as políticas públicas, e os conflitos que se desenvolvem com os habitantes que tentam defender um modo de vida no território.

Pretendemos perguntar-nos pelas lógicas de reprodução do capital nas cidades periféricas e pelas dimensões materiais, significantes e sensíveis que estruturam as experiências sociais possíveis.

\section{Introducción}

Preguntarnos por la vida en las ciudades, sus conflictividades y sus transformaciones significa preguntarnos por los rasgos, cambios y tensiones que organizan los espacios, tiempos y sentidos en los que la mayoría de los habitantes del mundo con-vivimos: vivimos con otros y compartimos, o no, los bienes comunes que constituyen nuestras condiciones materiales de vida, sean naturales o socialmente producidos. Desde la fundación de las reflexiones modernas sobre lo social, la pregunta ronda el cómo y por qué convivimos y qué principios deberían ser los que ordenen esa convivencia y la "distribución" de los bienes comunes: ¿la libertad?, ¡la igualdad?, ¿la propiedad?, ¿la justicia?, ¿el merecimiento?, ¿el progreso?

La dimensión temporal de la pregunta social es clave: cómo convivimos hoy, de qué modelos y matrices venimos y cuáles son las que estamos perfilando como tendencia a futuro. ¿Qué organiza el tiempo común?, ¿qué "carriles” y velocidades disponen o impiden choques y detenimientos? La dimensión espacial de esta pregunta es también nodal: dónde estamos, cómo cabemos y nos ordenamos unos al lado de otros, por dónde circulamos las personas y los objetos de los que nos valemos para la reproducción social, qué formas -materiales-, construimos para habitar, circular, pasear. Así, las reflexiones sobre las ciudades contemporáneas nos llevan a interrogar temporal y espacialmente las formas de ser/estar juntos, de ser/estar en sociedad, en ciudades capitalistas en las que "la luchas de clases" se expresa en la desigual apropiación de, y disputa por, el espacio urbano, y en los sentidos que reproducimos en dichas prácticas.

En el presente trabajo vamos a analizar el caso de la ciudad de Córdoba ${ }^{1}$ (Argentina), en torno a dos barrios lindantes al centro: barrio Alberdi y barrio San Vicente. El caso propuesto al análisis nos permite reflexionar sobre lo particular y lo general en el debate sobre "lo urbano". En lo particular, los casos presentan relevancia por su densidad de análisis: actores, conflictos, relaciones diacrónicas con las transformaciones en Córdoba y espacios en disputa. En lo general, develan ciertas dinámicas

y Cultura Contemporánea. Becaria CONICET-UNC. Integrante del programa de Ideología y Prácticas Sociales en Conflicto, Centro de Investigaciones y Estudios sobre Cultura y Sociedad (CIECS) de la Universidad Nacional de Córdoba y el CONICET. Áreas de estudios: segregación urbana, conflicto social, clases, educación secundaria en ciudades. Correo electrónico: katrimyers@hotmail.com ORCID: http://orcid. org/0000-0003-1785-6369

${ }^{1}$ Córdoba es la segunda ciudad con mayor población de la Argentina, con 1330023 habitantes, según el Censo Nacional de Población del año 2010, está ubicada en el centro del país y es capital de la provincia homónima.

\section{territarias 37}


${ }^{2}$ En el marco del programa de Ideología y Prácticas Sociales en Conflicto el proyecto "Embellecimiento estratégico de la ciudad: identificación y caracterización de patrones de circulación en Córdoba Capital" dirigido por la Dra. María Belén Espoz Dalmasso y codirigido por la Dra. María Eugenia Boito de Universidad Nacional de Córdoba de 2014 a 2015. Con anterioridad: "Urbanismo estratégico, experiencias de habitabilidad, circulación y desplazamiento en la ciudad. Indagación sobre vivencias/experiencias de las clases subalternas, Córdoba (2012-2013)” dirigido por la Dra. María Eugenia Boito y codirigido por la Dra. María Belén Espoz Dalmasso; "Urbanismo estratégico y segregación clasista. Identificación y descripción de algunasimágenes y vivencias de las alteridades de clase en el espacio urbano cordobés." dirigido por la Mg. María Eugenia Boito, de 2010 a 2011 y "Subjetividades $y$ contextos de pobreza. Deconstrucción de politicas habitacionales en el traslado defamilias a las nuevasciudades/barrio de Córdoba" dirigido por la Dra. Ana Levstein y codirigido por la Lic. María Eugenia Boito de 2005 a 2006.

\section{territarias 37}

de la acumulación capitalista y de la organización clasista de la sociedad que entendemos son relevantes para la construcción de una mirada crítica. Así, recuperamos una premisa de Harvey, quien, retomando el pensamiento de Marx, sostiene no se puede explicar una formación social solo desde las lógicas generales del capital, sino que se deben estudiar sus particularidades históricas sin abandonar esas leyes generales inherentes al sistema de reproducción social (Harvey, 2012).

En el vasto campo de estudios sobre ciudades, hemos situado nuestros intereses e interrogantes en las maneras contemporáneas en que Córdoba ha sido modificada por la convergencia de políticas públicas, que, asociadas con intervenciones privadas, reordenan el espacio en sentido clasista. Cuando decimos esto, hablamos de que la unión entre carney piedra en las urbes - es decir entre cuerpos, personas y materialidades que delimitan los espacios y trayectos, accesos e interacciones posibles, en sentido de Sennett (2003) — se relaciona con distintas políticas para las clases sociales, orientadas (en sentido hegemónico) hacia la segregación socio-espacial. Se trata, desde nuestra lectura, de políticas deliberadas de separación de los sujetos según clase y de reducción de instancias de encuentro entre clases. Esta políticas ocupan un amplio espectro que va desde políticas de ordenamiento residencial (planes habitacionales, normativas de edificación y de tipologías por sector, acuerdos con grupos empresarios legalizados por la figura de "Convenios Urbanísticos", etc.) hasta la planificación del transporte y la obra pública vial, como también las políticas de seguridad (detenciones arbitrarias de jóvenes de sectores populares que ingresan al centro, generación de cuerpos especiales de Policía para "prevención” y para "turismo"), políticas de fomento al turismo, políticas culturales, entre muchas otras. Las investigaciones ${ }^{2}$ que venimos realizando dan cuenta de que el objeto central de las actuales políticas del gobierno provincial y municipal, es la fragmentación del espacio en términos de circuitos particulares estructurados por experiencias desiguales de clase. De allí la referencia a los análisis de Walter Benjamin sobre las reformas de Haussman en París en la noción de urbanismo estratégico (Boito, 2013; Boito \& Espoz, 2014a; Boito \& Espoz, 2014b) que enfatiza la intencionalidad política de los diseños urbanos en miras a ocluir la emergencia del conflicto social y regular las interacciones entre clases.

Empezaremos reconociendo las transformaciones y disputas puntualizadas en este trabajo, ubicándolas en el marco de un proceso urbano mayor de refundación de espacios, tiempos y experiencias, para luego detallar características de los barrios que otorguen densidad al caso propuesto. Por último, presentamos un análisis que atraviesa y es atravesado por el río Suquía y por la circulación de personas y mercancías; ambos como síntomas de las transformaciones estudiadas y de la fluidez y de la direccionalidad de las dinámicas capitalistas contemporáneas.

Cecilia Michelazzo, Katrina Salguero Myers 
La estrategia metodológica ha seguido ese mismo recorrido de aproximaciones y distanciamientos sucesivos y complementarios. Aproximaciones a los sentidos y experiencias de los sujetos que habitan los barrios y distanciamientos para comprenderlas en sus atravesamientos por las dinámicas estructurales del capital; aproximaciones a las acciones de resistencia y conflictividad y distanciamiento para reconocer los discursos y acciones hegemónicas que con ellas se tensionan; aproximación a los cuerpos vivos y distanciamiento para leer los flujos de capitales.

En este artículo vamos a referenciar principalmente datos construidos mediante la observación participante en las reuniones y actividades públicas e internas de las dos organizaciones que articulan la disputa por el territorio en los barrios referidos: Multisectorial Defendamos Alberdi, durante 2014 y 2015, Red de Vecinos y Asociaciones de San Vicente, durante 2015 y 2016 , pero también entrevistas en profundidad con informantes claves - $\mathrm{CO}^{-}$ rredores inmobiliarios con actuación en la zona, habitantes "históricos", participantes de dichas organizaciones y referentes de instituciones de los barrios-. En el caso de Alberdi se contó con información sistematizada a partir de una serie de talleres que se organizaron en conjunto con la Multisectorial Defendamos Alberdi sobre los ejes comunicación y cultura barrial, organización y participación, migraciones y convivencia ${ }^{3}$. Dicho trabajo de campo de orientación socio-etnográfica se complementa con el análisis de datos de fuentes secundarias: informes y trabajos de investigadores locales, documentos de políticas públicas urbanas, información de la prensa gráfica y publicidades de emprendimientos inmobiliarios ${ }^{4}$. Procuramos de esta manera "captar" las particularidades que asume la operatoria de la acumulación capitalista y la segregación en el espacio urbano cordobés, desde aquel doble enfoque que nombrábamos: reconociendo tanto las dimensiones "macro" del fenómeno, como las vivencias, materialidades y prácticas concretas y situadas que organizan este estar juntos/ separados en la ciudad.

\section{Barrios San Vicente y Alberdi: refundados en el orden urbano}

Resulta difícil hablar de estos barrios como pasibles de ser fundados. Ambos, San Vicente y Alberdi, son barrios lindantes al centro de la ciudad, antiguos lugares residenciales con huellas de esa historia: casonas viejas, familias "tradicionales", fábricas y talleres de principios del siglo pasado, que les valen el nombre de "barrios pueblo" (ver figura 1). Estos barrios cordobeses cuentan con historiadores propios, relatores del pasado común y anécdotas que unieron a los residentes y los unen al presente: corsos, huelgas, estudiantes, terratenientes, clubes, molinos, río.

¿En qué sentido decimos que San Vicente y Alberdi son "refundados" entonces? Como bien Derrida nos recuerda (1997) la posibilidad misma de acontecimiento tiene siempre algún rasgo de conservación y alguno de fundación. ¿¿De qué y
${ }^{3}$ En el marco del proyecto de transferencia de resultados de investigación "Territorio, convivencia e identidad en Alberdi" dirigido por María Eugenia Boito, avalado y financiado por el Ministerio de Ciencia y Tecnología de la provincia de Córdoba.

4 Como mencionábamos anteriormente, este trabajo integra un abordaje colectivo mayor, en algunos de cuyos resultados parcialesse ha profundizado en diversasfuentes, y también en las experiencias de actores que habitan otros sectores de la ciudad: desde 2005 sobre el plan habitacional "Mi Casa, Mi Vida" y focalizando en algunas de las ciudades barrio resultantes del mismo, inclusive sobre villa La Maternidad, la única villa (de más de ochenta) que resistió el "traslado", ubicada en "la entrada" de San Vicente. Luego analizando transformaciones en la zona céntrica y edificios públicos en el marco de los festejos por el Bicentenario de Independencia (2010), barrios periféricos construidos por ayuda mutua en cooperativas asistidas por otras politicas de vivienda en los 90, barrios pericentrales sometidos a diversos niveles de "gentrificación" entre ellos Alberdi y San Vicente, también Güemes

territarias 37 
$\Longleftarrow$

y San Martín y la villa El Tropezón que ha venido sufriendo varias etapas de intentos de desalojo por una obra vial de gran escala. La opción metodológica esprincipalmente cualitativa, retomando y constando la convergencia de resultados con análisis demográficos y de indicadores como permisos de construcción, extensión de suelo urbanizado, etc. de otros trabajos (como Marengo, 2013, Molinatti, 2013; Capdevielle, 2014; Peralta \& Liborio, 2014). El trabajo socio-etnográfico -observación participante, entrevistas en profundidad, encuentros expresivos creativos - se complementa con análisis de politicas públicas urbanas (Plan Director de Córdoba 2020, lineamientos del IPLAMInstituto de Planificación del Área Metropolitana-, el programa habitacional "Mi Casa, Mi Vida") entre las que incluimos las de Seguridad y Turismo, su presentación mediática y publicidad de empresas constructoras.

\section{territarias 37}

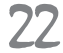

Figura 1. Córdoba y sus "barrios pueblo"

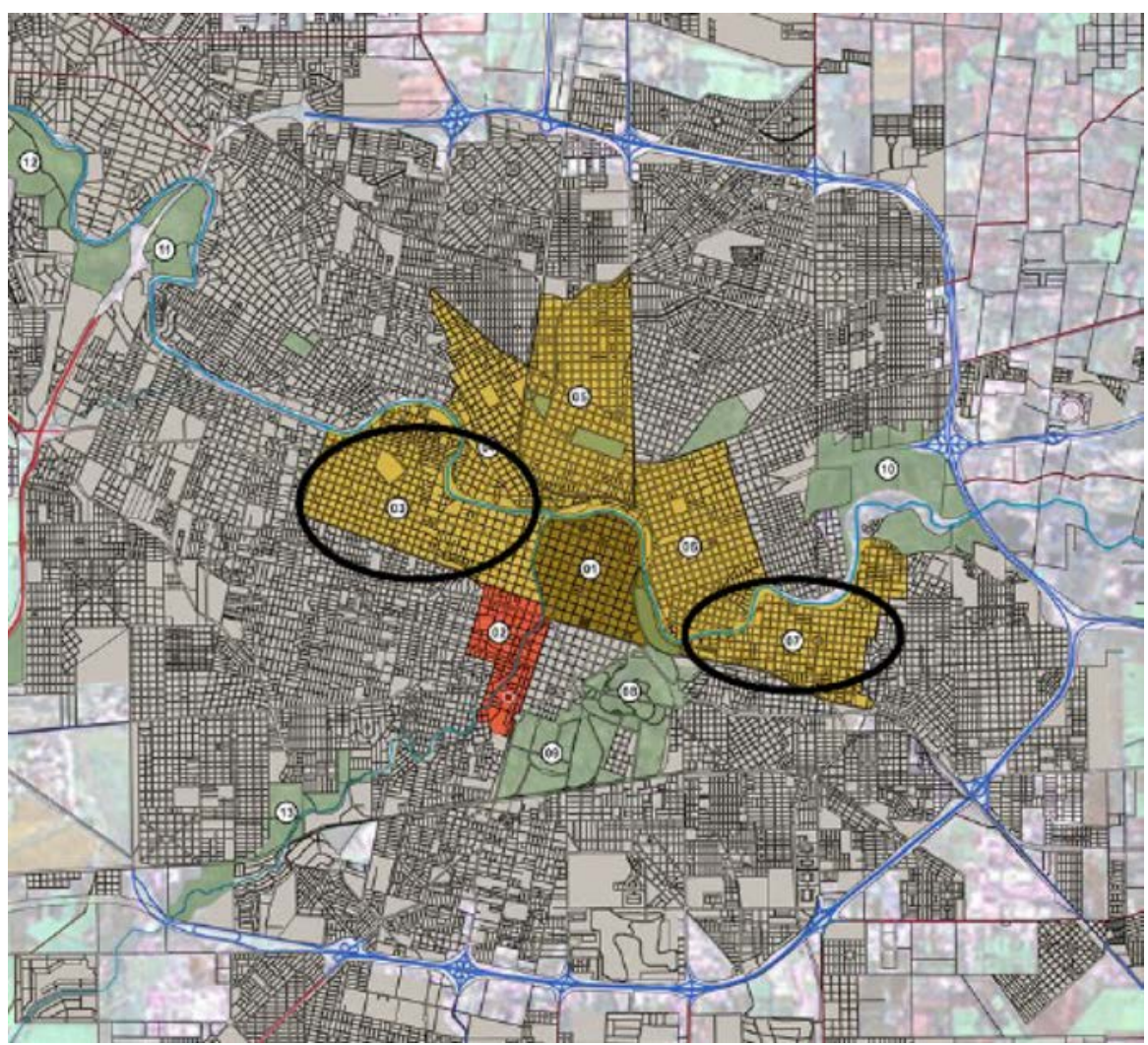

Fuente: Gentileza de Ailen Suyai Pereyra, sobre plano de la Municipalidad de Córdoba (2016).

sobre qué puede construirse, fundarse y acontecer como disrupción "lo nuevo" sino de lo que previamente existe? Sea en su negación, en su ocultamiento, en su destrucción o en su reconocimiento; el acontecimiento emerge del continuo del tiempo como refundación, como nacimiento sancionado y siempre arbitrario de algo que ya había nacido. "El Estado tiene miedo de la violencia fundadora, esto es, capaz de justificar, de legitimar (begrüden) o de transformar relaciones de derecho, y en consecuencia de presentarse como teniendo derecho al derecho" (Derrida, 1997, p. 90). Luego continúa: "esa violencia es ciertamente legible, incluso inteligible, puesto que no es extraña al derecho" (p. 90). Así, el autor argelino-francés explica la aporía del acontecimiento: lo que al fundar lo nuevo es solo inteligible si se conserva lo antiguo para su interpretación.

Cecilia Michelazzo, Katrina Salguero Myers 
En este sentido, toda fundación de un nuevo orden - social, urbano, de inteligibilidad, etc. - supone, hasta cierto punto, la destrucción creativa: la destrucción del régimen anterior, de lo existente, de lo visible, de lo presente ${ }^{5}$ para la refundación de lo novedoso, siempre con algún escombro de pasado. En nuestro análisis de las ciudades, este proceso de destrucción creativa se da, en el ordenamiento urbano, en un sentido clasista. Implica en términos generales, que los borramientos, relocalizaciones forzosas, desplazamientos y desposesiones se producen para las clases sociales subalternas; mientras que las relocalizaciones volitivas, la acumulación de capital y el desenvolvimiento de zonas de placer y de libertad se dan para otras.

¿En qué sentido hablamos, entonces, de ordenamiento clasista del espacio urbano? En un sentido materialista, situado y relacional - puesto que clases refiere, necesariamente, a lucha de clases- La pertinencia epistémica y política de esta noción, en su desigual atravesamiento de los grupos y los sujetos empíricos y al expresarse en conflictos de maneras novedosas, requiere de la escucha y de la visión atenta para considerar las condiciones de observabilidad de estas formas/contenidos de lo conflictual.

Esta desigual y situada existencia de grandes conceptos como lucha de clases está en sintonía con lo que otros autores plantean sobre, por ejemplo, la gentrificación. En esta dirección proponen Janoshka \& Sequera (2014) una rearticulación crítica del concepto gentrificación para América Latina puesto que, a pesar de las particularidades localizadas de dicho proceso, es un concepto que reinstala la política en el debate sobre lo urbano. Constatamos, al igual que los autores citados, que los desplazamientos, recambios poblacionales y procesos de renovación de ciertos espacios benefician a las clases dominantes - que reservan para sí "las mejores ubicaciones", pero también "las mejores inversiones" que garantizan el incremento de su capital - en detrimento de las dominadas, sobre las cuales se ejercen distintos tipos de violencias.

En Argentina, algunas de esas manifestaciones concretas y situadas de la lucha de clases y de los - emparentados - procesos de gentrificación se han organizado en torno a villas y asentamientos precarios rebelados contra sus relocalizaciones/desalojos ya sean compulsivos o "consensuados" a través de algún plan habitacional. Otras se dieron, también, en torno al rechazo de los vecinos a recibir esos nuevos habitantes "relocalizados". Otros conflictos se expresan en torno a la posibilidad de circular por el espacio público, las calles, el centro (en relación a las detenciones arbitrarias de la Policía a los jóvenes de sectores subalternos $)^{6}$. En otros casos se dan por la conservación de edificios históricos y por la defensa del patrimonio cultural de sus barrios, pero también por la conservación de sus espacios de vida con ciertas características.

Es este último el caso que abordamos aquí, siendo el de dos barrios de la ciudad de Córdoba que presentan rasgos históricos, geográficos y demográficos similares:
${ }^{5}$ En un sentido distinto, Benjamin señala el intimo lazo entre la construcción y la destrucción, al proponer que quien quiere crear siempre destruye; bay un momento de barbarie como limpieza del terreno para la generación de lo nuevo. Sin embargo aquí -y siguiendo con Benjamin-la destrucción como catástrofe con relación a las condiciones de existencia y las posibilidades vitales de los miembros de las clases subalternas, es construida $y$ percibida como un simple "dato" mediante procesos de mediatización que se destinan a la "ciudadania".

"También Janoshka er Sequera (2014) analizan las tramasentre securitización y gentrificación.

\section{territarios 37}

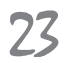


${ }^{7}$ Mencionaremosbrevemente algunas características de las acciones colectivas que expresan este conflicto en los barrios analizados, que no son objeto específico de este trabajo, pero sin embargo entendemos que expresan rasgos y dinámicas del conflicto por el espacio, que exceden los barrios referidos y sus objetos de protesta e intervención.

${ }^{8}$ Es interesante la reivindicación de un "tiempo" común, en el caso de Alberdi, en la marcha con que cada año se conmemora la demolición de la chimenea de la antigua Cervecería en 2016 se hizo "sonar" el silbato de la fábrica, sonido presente en los recuerdos $y$ relatos de muchos de los habitantes del barrio.

\section{territarias 37}

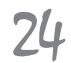

Alberdi y San Vicente. Estos territorios sociales se configuran como espacios en disputa. La "refundación" es, entonces, la sanción de un "nuevo barrio" acorde, claro está, a las necesidades del capital. Esta refundación no deja de ser conflictual y siempre abierta.

La disputa adquiere, solo de a momentos, los rasgos y las dinámicas de "protesta social", mediante acciones que instalan en las calles recursos expresivos que impugnan los impactos de las tendencias socioeconómicas y sociourbanas que modifican la vida barrial. Pero esta disputa se hace visible a través de diferentes modalidades que evidencian cierta experiencia y expectativa de clase que oscila entre mantener/modificar en un sentido distinto a las mencionadas tendencias, la vida en el territorio ${ }^{7}$. Por lo dicho, el objeto del conflicto se caracteriza también por la indefinición, al ser configuración en proceso; presente tensionado en resultantes de la disputa social. Sin embargo, el principal eje de conflictividad es la resistencia a esta refundación del territorio de vida. Esta se manifiesta más claramente en la obstrucción colectiva-corporal de demoliciones, pero hunde sus raíces en procesos aún más complejos que rechazan la refundación significante del barrio y las experiencias que hacen posibles; y que se expresan en la voluntad de "seguir siendo barrio".

La Red de Vecinos y Asociaciones de San Vicente y la Multisectorial Defendamos Alberdi surgen de la voluntad co- $^{-}$ lectiva de detener el avance y la violencia “desarrollista” expresada en la demolición de íconos identitarios de cada barrio. En el caso de San Vicente, fue la resistencia a la demolición de la casona del Sindicato de Conductores de Trenes "La Fraternidad", en 2009; en Alberdi, fue la oposición a la demolición de la chimenea de la antigua Cervecería Córdoba, en 2010. Ambos grupos se formaron por la resistencia a un acontecimiento emergente: el “AAlto!”, “¡Ya Basta!”, "Paren de demoler". La voluntad colectiva de detener el avance del proyecto desarrollista, el deseo de irrumpir en el desarrollo "pacífico" del modelo hegemónico de ciudad, unifica ambos procesos.

Con numerosas diferencias entre sí, los objetivos de estas organizaciones convergen, sin embargo, en la voluntad de sostener/promover una "forma de vida de barrio", un objetivo difuso, pero claramente opuesto a la privatización de la vida de los complejos cerrados de departamentos y asociado a la reivindicación de lo común: espacios comunes ${ }^{8}$, públicos, de encuentro, el patrimonio arquitectónico, histórico y cultural, la posibilidad de participar en las decisiones sobre la planificación del barrio que habitan y la posibilidad de continuar habitándolo, frente a formas más o menos veladas de expulsión, desde desalojos a casas de inquilinato, alquiladas por piezas a inmigrantes de países limítrofes a causa de la venta de dichos inmuebles para su demolición y posterior edificación, típicamente en Alberdi, hasta la expulsión "light" (Carman, 2011b) mediante el aumento de impuestos, servicios y precios de los bienes que se comercializan.

Cecilia Michelazzo, Katrina Salguero Myers 
Estos dos grupos, constituidos como actores en conflicto, tienen reuniones semanales, agendas comunes de actividades, proyectos e intervenciones en el espacio público. Algunas acciones son defensivas, cuando se trata de amenazas o ejecuciones de demolición o desalojo, en las que no solo se pone el cuerpo sino que se movilizan todos los recursos legales y técnicos disponibles. Otras acciones, en cambio, son propositivas, destinadas a revitalizar aquello común que se reivindica: intervenciones artísticas en el espacio público - cine al aire libre, organización en festejos de carnaval-, murales, reparación o construcción de plazas, "canchitas", recorridos o caminatas por los hitos del patrimonio histórico del barrio, propuestas de talleres y actividades con vecinos, etc. En ambos casos se busca cuestionar en el sentido común las ideas de "progreso" y "desarrollo" y los vínculos anónimos, deshistorizados y mercantilizados entre vecinos. Cuestionan, así, las matrices de sentido que legitiman y dan sustento a las intervenciones públicas y privadas desarrollistas, incluso la absoluta potestad de los propietarios de los inmuebles para demoler o construir, ya sea dentro o fuera de la normativa, entendiendo que todo lo precedente afecta el "bien común" del barrio (ver figura 2). En esta disputa las organizaciones han emprendido y emprenden proyectos comunicacionales, revistas como La Chimenea en Alberdi y el Portal de San Vicente, blogs, Facebook, programas de radio semanales como "La Chimenea" en Alberdi o "Vecinos en Red" en la Radio Comunitaria la 5ta Pata, en
Figura 2. Volante producido por la Multisectorial Defendamos Alberdi
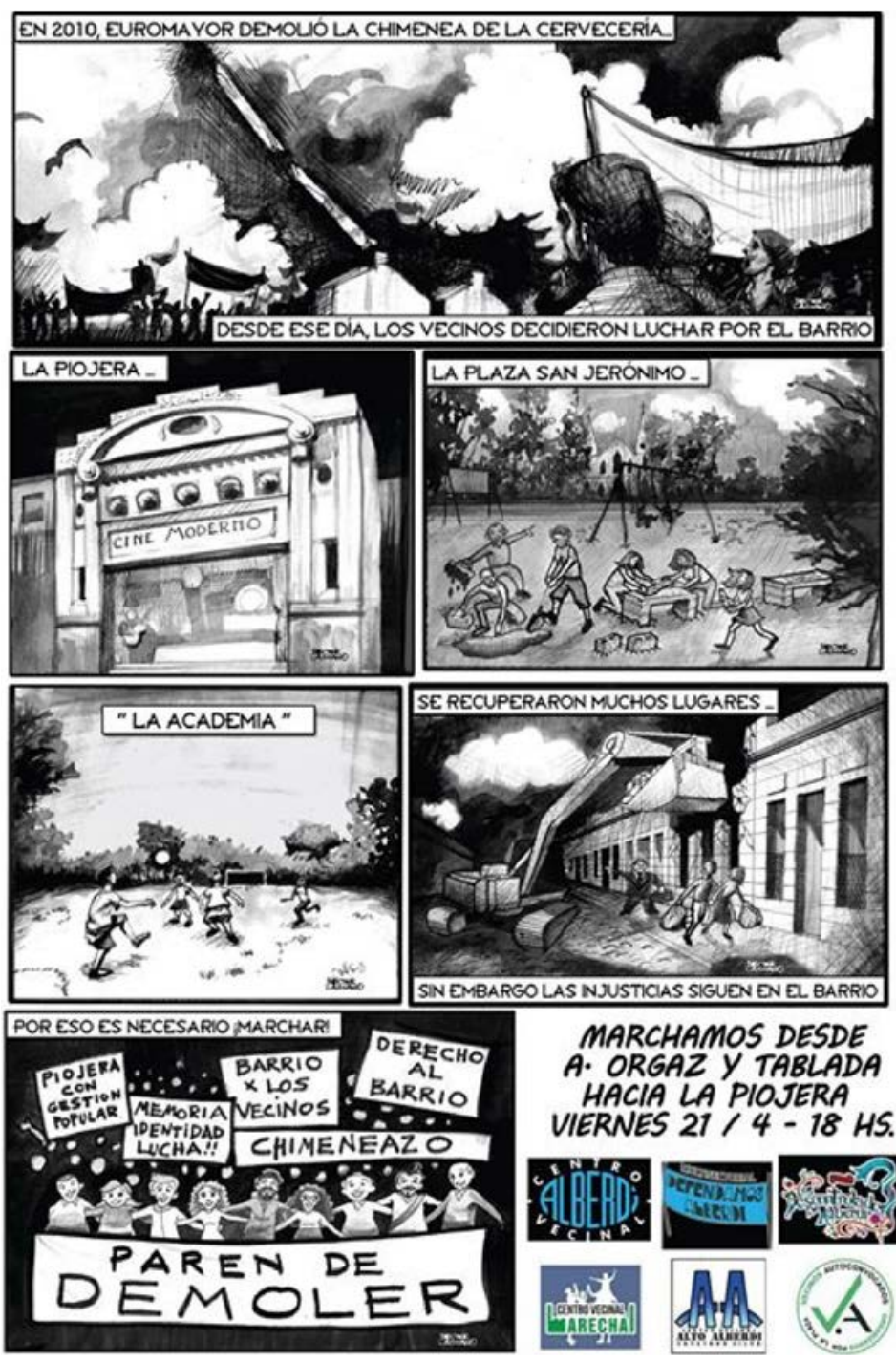

MARCHAMOS DESDE A. ORGAZ Y TABLADA HACIA LA PIOJERA VIERNES $21 / 4-18$ HS.
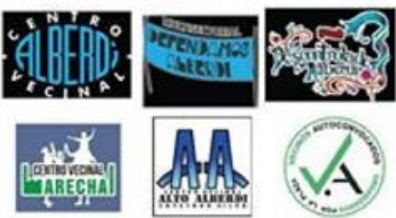

Fuente: Multisectorial Defendamos Alberdi (2016).

San Vicente, visitas guiadas en autobús o a pie para difundir la historia del barrio, entre muchas otras.

territarias 37 
A pesar de las diversas, intensas y creativas acciones de resistencia, el avance del negocio inmobiliario no se ha detenido en sus acciones de despojo y ocupación territorial. El rol del Estado es fundamental: adaptando normativas, incumpliendo el deber de defender incluso lo que sí está reconocido legalmente como "patrimonio", negociando con los inversores "retribuciones" ad hoc para suplir las faltas legales, como obligándolos a conservar la fachada de un edificio antiguo para demolerlo, permitiendo la destrucción de otro inmueble bajo la promesa de instalación de un "museo del barrio" o "espacios culturales" de distinto tipo. En este sentido existen más leyes que protegen las fachadas que a los ocupantes desalojados. Cabe decir, sin embargo, que la mayoría de los desalojos ocurren en la invisibilidad y sin mayores resistencias, puesto que se trata de grupos empobrecidos o inmigrantes, a veces indocumentados. De más está decir, por otro lado, que sobre "lo común", sobre la "forma de vida de barrio" no hay legislación que la defienda.

Las transformaciones en barrio San Vicente y Alberdi (lejos de ser exclusivas de la ciudad de Córdoba) exponen el lugar de lo urbano como el tiempo y el espacio para la reproducción ampliada del capital (Harvey, 2004). Allí, el reordenamiento hegemónico intenta imponer nuevas formas de apropiarse del espacio, como mercancía acumulable, desplazando a las y los habitantes. La expresión más clara de esto en los casos estudiados es, como veníamos refiriendo, la destrucción de edificaciones tradicionales (casonas, fábricas, etc.) y con ello el borramiento de las condiciones materiales que permitían ciertas maneras de significar y vivir en el barrio, así como la presencia de actores/clases que van desapareciendo, expulsados o desalojados de maneras más o menos sutiles, más o menos explícitas, más o menos dulcificadas, "alienados" de la posibilidad de habitar/ circular por estos escenarios.

Como hemos mencionado, sobre estas demoliciones de lo "tradicional", se construyen edificios o complejos de apartamentos, pensados principalmente como “inversiones". Constituyen unidades habitacionales y espacios de consumo para clases altas, que modifican las maneras de vivir/sentir/habitar y tramar las memorias individuales y colectivas con las vivencias del presente.

Los cambios clasistas para la reproducción del capital son materiales; pero esto no solo se objetiva en los edificios que se derrumban o los nuevos que se construyen sobre los escombros, sino también en la naturaleza sensible de las prácticas de los sujetos que viven o dejan de vivir en ellos, en los haceres y sentidos de quienes habitan y circulan; en lo que se facilita o se prohíbe hacer en los lugares "refuncionalizados". Es, al fin de cuentas, la resemantización de la vida en el territorio lo que está en pugna.

En líneas generales, el hecho de constituirse como una zona atractiva para los inversores, ser barrios con importante patrimonio histórico y arquitectónico de la ciudad y tener una población heterogénea tanto en términos étnicos como de grupos

Cecilia Michelazzo, Katrina Salguero Myers 
económicos ${ }^{9}$, se traduce en diversas expresiones de conflictividad. Cada eje de conflictividad puede ser, además, ambiguo: el patrimonio arquitectónico, histórico, es un valor identitario defendido por las organizaciones, pero es también un valor agregado para el mercado, un "plus cultural" que atrae inversores y desarrollo turístico. En convergencia con lo que han señalado Thomasz (2014) y Carman (2011b) para ciertos barrios porteños, a veces el argumento cultural y patrimonial se vuelve en contra de los habitantes de sectores subalternos. Bajo el discurso legitimante de "recuperación" para "la ciudad" de su patrimonio cultural ${ }^{10}$, se los despoja de su territorio y se convierten las "fachadas" en piezas de conservación o museo, que además aumentan el valor de la mercancía "barrio" nombrada ahora como "ubicación".

De este modo la lógica del patrimonio (revitalizada como tendencia en nuestra ciudad por los menos durante la última década) encuentra coincidencias profundas con la racionalidad del turismo (en la que también coinciden Estado/Mercado) y, en cierta manera, puede ser interpretada como la materialización de una visión museística de la cultura que prioriza "pasado/conservación" para el consumo antes que la "creatividad del presente cultural" que actualizan los habitantes de los barrios. Se plantean así ciertas ambivalencias en torno al sentido del patrimonio, puesto que mientras es objeto de apropiación como valorizador y como adorno para el mercado y el turismo; condensa para cier- tos habitantes de los barrios, la identidad barrial y la memoria colectiva.

A pesar de sus similitudes, el desarrollo inmobiliario ha sido desigual entre ambos barrios: en Alberdi el avance de la ciudad "refundada", "embellecida" está mucho más consumado que en San Vicente. Entendemos que esto se debe a dos dimensiones del espacio: cómo se relaciona cada barrio con el centro, por un lado, y a dónde nos lleva atravesarlo, por otro. Alberdi presenta una continuidad geográfica fluida con la zona céntrica: todas las calles que corren de este a oeste por el centro de la ciudad llevan hacia Alberdi. Pero además, la Avenida Colón es un corredor que conecta el centro con la zona oeste y noroeste, que es un área de gran crecimiento poblacional y de desarrollo de emprendimientos habitacionales y comerciales para clases altas, así como camino a countries y barrios cerrados de distinto tipo, puesto que en esa zona comienzan las sierras.

San Vicente, en cambio, presenta hoy un desarrollo inmobiliario significativamente menor. Por la doble dimensión que proponíamos, San Vicente colinda con el centro hacia el este y se conecta solo por la confluencia del Boulevard Perón y la calle Agustín Garzón. Esta área fue fuertemente intervenida por el Estado y el Mercado desde 2004: por el desalojo de villa La Maternidad y la construcción de la nueva terminal de ómnibus y complejos comerciales y habitacionales. Sin embargo, la villa nunca pudo ser desalojada del todo por la resistencia de un grupo de sus habitantes y no se pudo concretar la destrucción de los
9 "Entendemos que existen territorios en la ciudad de Córdoba que se construyen en la co-presencia de sujetos que habitan condiciones socio-económicas disimiles, y se distinguen en sus dinámicas y configuraciones de las "comunidadesvalladas" (Harvey, 2008). Esta categoria intenta construir lugares conceptuales desde los cuales estudiar los espacios urbanos que no pueden entenderse como cerrados y homogéneos" (Salguero, 2015, p. 204).

${ }^{10}$ Como ocurre también, veremos más adelante, con el río como "patrimonio" en este caso "natural".

territarias 37

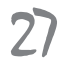


${ }^{11}$ Frase de un corredor inmobiliario de la empresa Silvestre, de barrio San Vicente.

territarios 37

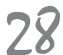

rasgos y las dinámicas que particularizan la vida de las clases subalternas en la zona. Pero además, en la segunda dimensión relacional que proponíamos, "San Vicente no lleva a ningún lado" ${ }^{11}$ : como corredor de circulación, San Vicente lleva a barrios humildes y villas de Córdoba.

\section{El río como dimensión de disputa y como síntoma}

El río Suquía atraviesa la ciudad de Córdoba de oeste a este. En ese recorrido, pasa por Alberdi, el Centro y luego San Vicente - todos al sur del río-. Resulta un hilo conductor de los espacios bajo análisis, pero además se constituye como síntoma de dos tendencias urbanas en relación a la naturaleza y los espacios verdes: en un caso se lo ha trabajado como lugar a revalorizar, como espacio de goce y conexión con lo natural-deseado (ver figuras 3 y 4); en el otro, el río es su antítesis: el basural irregular pero permitido, el lugar del abandono, el lugar del tránsito veloz y en actitud de huida (ver figuras 5 y 6 ).

Figura 3. Torres del Río. Emprendimiento inmobiliario a la vera del río Suquía

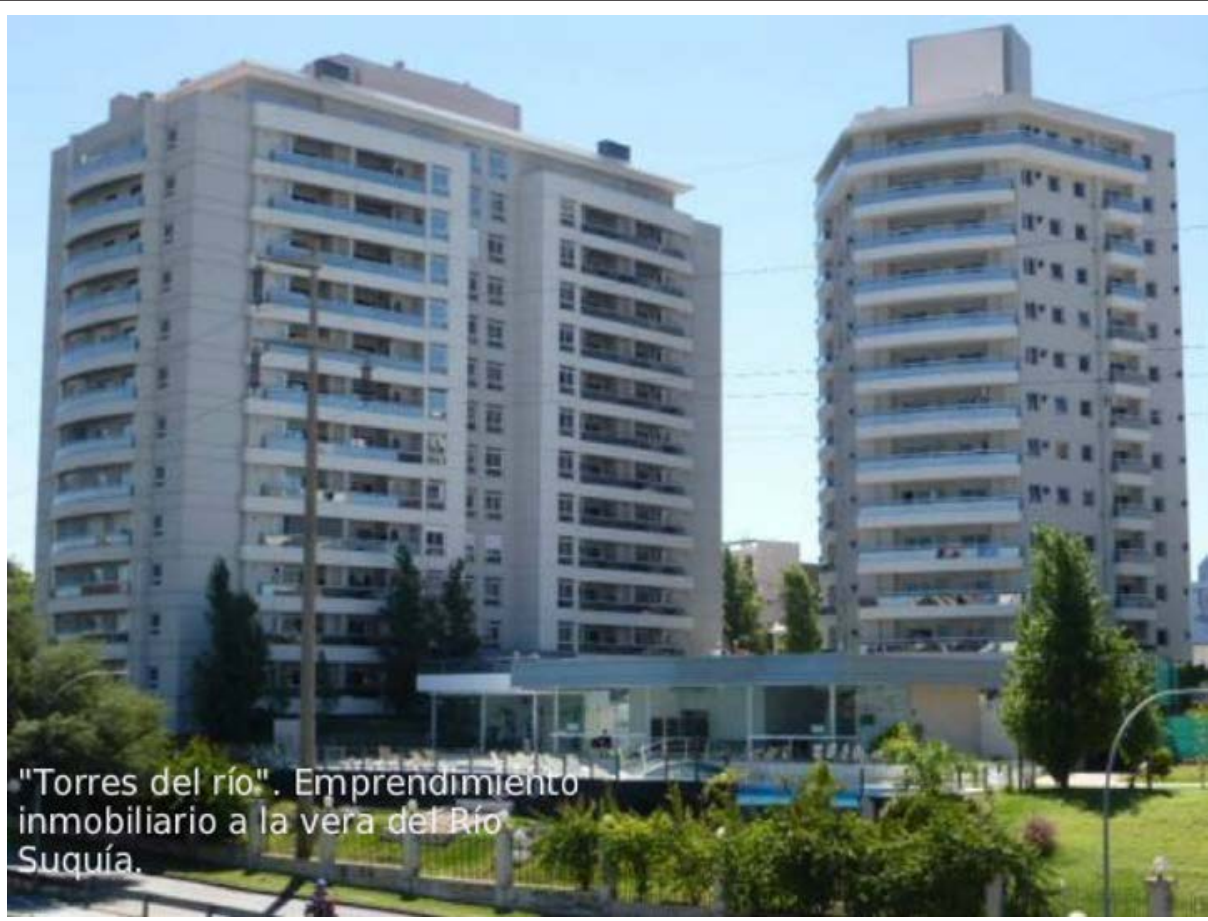

Fuente: Grupo ESMAR (2016). 
Figura 4. Río Suquía en la zona céntrica

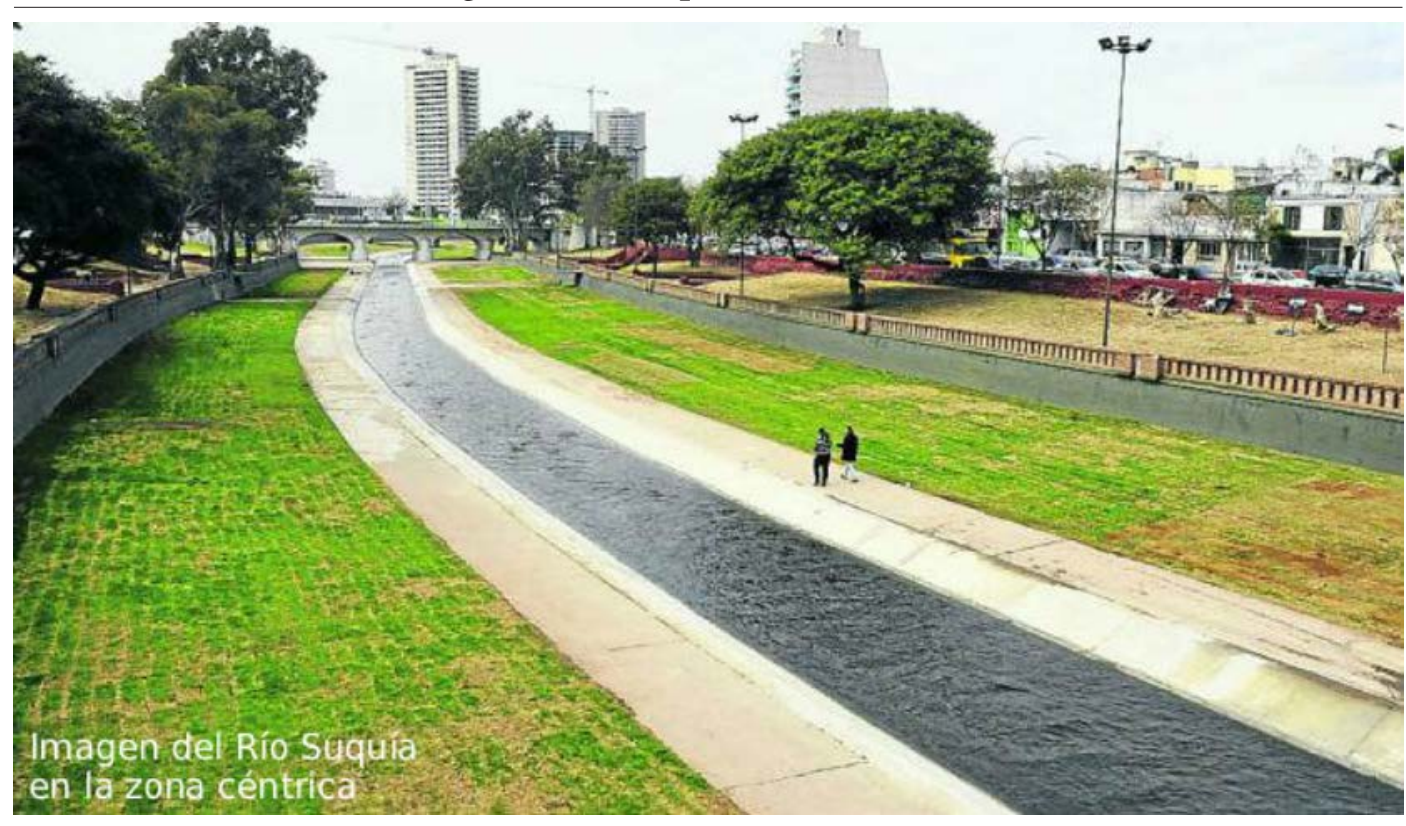

Fuente: Nicolás Bravo (2013).

En el caso de Alberdi (así como del Centro y también más hacia el oeste), el río Suquía viene siendo objeto de intervenciones orientadas al "saneamiento" y "recuperación" por parte de los sucesivos gobiernos desde el retorno de la democracia (década del ochenta), que implicaron desplazamientos y traslados de las poblaciones populares asentadas en sus orillas. En un primer momento se construyó una vía rápida de circulación de automóviles, la Avenida Costanera. Entre esta y el río se parquizaron algunos sectores, entre ellos "La isla de los patos" 12 , en Alberdi. En los primeros años de este siglo se permitieron construcciones en altura en los márgenes, habilitando grandes y rentables emprendimientos inmobiliarios con el valor agregado de la vista al río, en un momento en que se valora y publicita el "retorno a lo natural" en las opciones habitacionales ofrecidas por el mercado ${ }^{13}$. Pero las posibilidades de vivir en contacto con el "verde", la naturaleza y el río se reservan a quienes puedan sostener económicamente la rentabilidad de los "desarrollos", donde ya los habitantes históricos fueron trasladados compulsivamente a la periferia, vía plan habitacional a gran escala ${ }^{14}$. Mientras que el análisis que realiza María Carman (2011a) para el caso de las zonas ribereñas de Buenos Aires, hace énfasis en los usos de la "cuestión ambiental" para configurar conflictos por el espacio urbano,
${ }^{12}$ Isla en el río en la que se realizan ferias y que concentra mucha de la actividad recreativa de la zona; lugar también de encuentro de la comunidad peruana los días domingo.

${ }^{13}$ En Espoz, Michelazzo \& Sorribas (2010) presentamos un análisis de la construcción mediática de este valor en las páginas institucionales de los principales "desarrollistas urbanos" de la ciudad yen el diario de mayor tirada en la provincia. En Boito \& Michelazzo (2014) analizamos cómo las referencias a lo "perde" o lo "natural" aparecen entre los principales valores que los habitantes de las ciudades barrio otorgan a los espacios que elegirian para vivir, que consideran los más lindos de la ciudad y los que eligen para pasear, a partir de una encuesta realizada en 2013.

14 Sobre el plan "Mi Casa, Mi Vida” que implementó elgobierno provincial desde 2003 como politica expulsógena y segregacionista hemos trabajado en profundidad. Ver por ejemplo a Boito \& Espoz (2014a; 2014b) y Boito \& Michelazzo (2014).

\section{territarias 37}


Figura 5. Viejas fábricas abandonadas en San Vicente

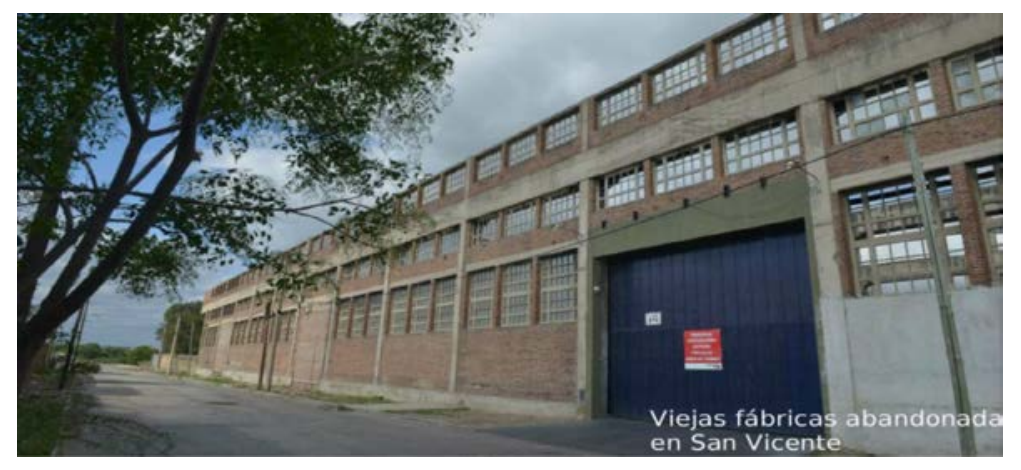

Fuente: Elaboración propia (2014).

en este caso "la naturaleza" se presenta directamente como plus a las mercancías urbanas a disposición - casa, recreación, circulación-.

Si las clases más altas se mudan a "la naturaleza" en los countries y barrios privados de la periferia - movimiento favorecido también por la construcción de vías rápidas de acceso en automóvil- los sectores económicos medios y medios-altos encuentran en los grandes complejos a orillas del Suquía, el contacto con "lo verde" sin alejarse del centro.

Una mirada sobre estas operatorias de "recuperación" del río — tal es la denominación oficial - nos permite notar de manos de quién se "recupera" y para

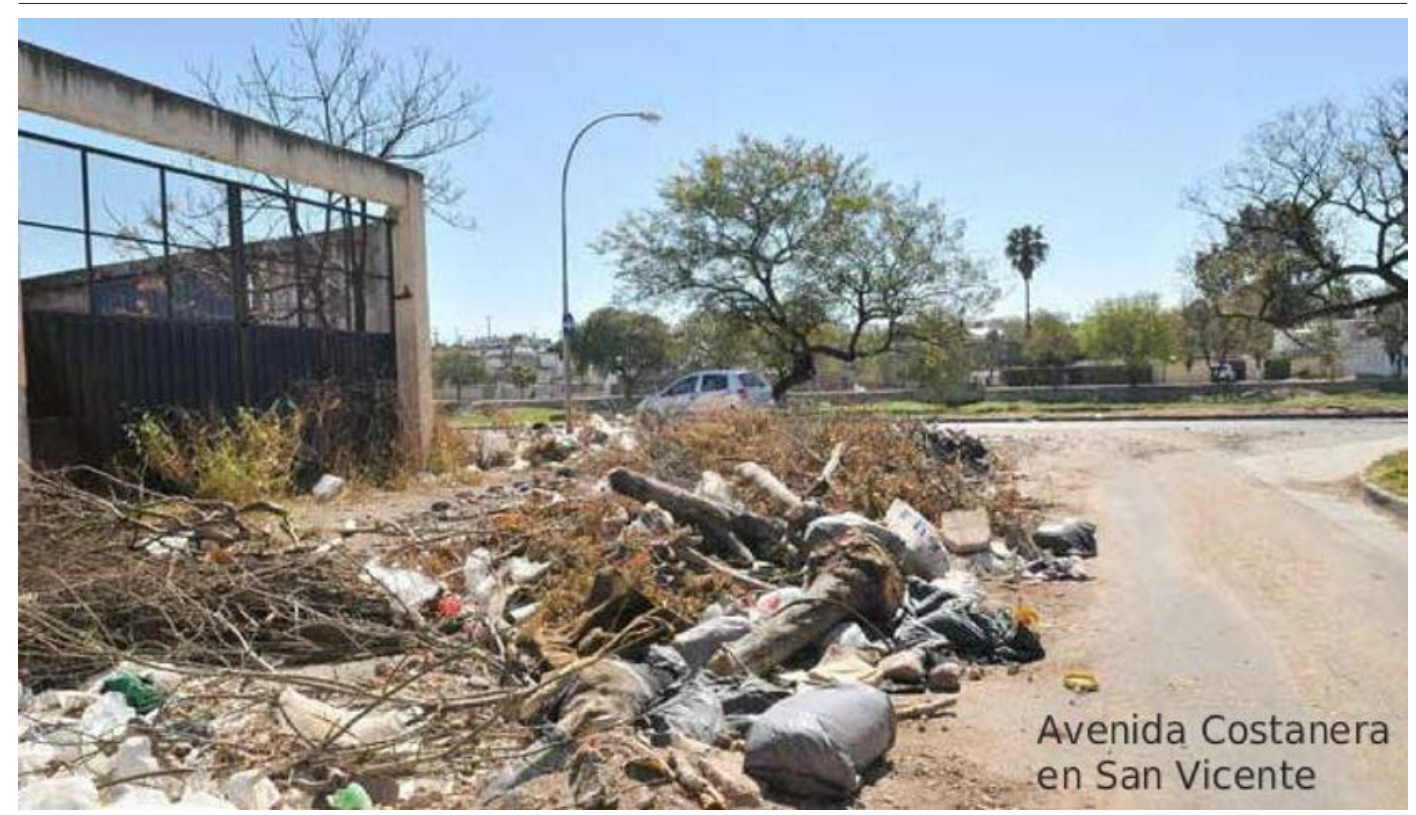


quiénes es lo recuperado. En ese sentido podemos destacar un conflicto desatado en barrio Alberdi los primeros días de junio de 2015: la Municipalidad arrasó con una canchita de fútbol comunitaria ubicada a metros del puente Tablada, en el marco del "rediseño" y ampliación de la Avenida Costanera Ramón Mestre. Vecinos y vecinas del lugar, con apoyo de la Multisectorial Defendamos Alberdi, cortaron la calle tres días consecutivos sin obtener ninguna respuesta de las autoridades municipales. Los miembros de esta instancia de resistencia y lucha colectiva reclamaron su derecho a participar de las decisiones en torno a las modificaciones en su barrio ("Vecinos reclaman contra la demolición de una cancha", 2015). Finalmente, los funcionarios municipales se presentaron y firmaron un compromiso de reconstruir la canchita, modificando unos metros tanto su ubicación inicial como el proyecto de ensanchamiento de la avenida.

Este hecho de protesta expresa una de las direccionalidades que organiza la acción colectiva en este escenario urbano: de lo que se trata es de mantener "el modo de vida barrial".

En el caso de San Vicente, el río presenta una lógica de apropiación y desvalorización opuesta pero convergente. Desde el final de la zona céntrica, el curso de agua cordobés está abandonado de la política pública: no cuenta con márgenes, ni parquización, ni iluminación; la avenida Costanera como vía rápida que costea el río Suquía está en terribles condiciones. En sus márgenes, en lugar de complejos habi- tacionales y edificios en altura, se pueden ver basurales y viejos edificios de fábricas abandonadas.

San Vicente fue, durante parte del s. XX, un importante polo de talleres y pequeñas fábricas (D’Amico, 2008), que con las transformaciones neoliberales de los últimos cuarenta años dejaron de existir. El polo económico de la zona no se concentra ya en la producción y manufactura, sino en la comercialización: la calle San Jerónimo es un centro comercial de relevancia, con comercios, entidades bancarias y dependencias públicas de todo tipo.

Entendemos que ambas formas de relación con el río Suquía, desde la política urbana estatal y privada, resultan convergentes: el uso/consumo de la naturaleza embellecida como derecho accesible a ciertos grupos socioeconómicos; el padecimiento/huida de la naturaleza abandonada y contaminada para otros.

En este sentido, es posible reconocer una tendencia clara respecto al acceso al hábitat y a la naturaleza según posibilidades económicas: para los grupos más acomodados, un hábitat renovado y lleno de opciones mercantiles para ser consumidas; la naturaleza como entorno protegido y embellecido para el ocio y el disfrute. Para los grupos empobrecidos, el hábitat es una política compulsiva y la naturaleza es un entorno hostil e inhabitable.

En la línea de reflexiones que venimos proponiendo y que retomaremos en el apartado siguiente, el río como recurso común cobra existencia y habilita el encuentro y experiencias de placer cuando territarias 37 
está asociado a la producción de valor, de ganancia de algún tipo. En este caso, al revalorizar áreas para la inversión inmobiliaria y para el comercio de alquileres, el río y su entorno son revitalizados, iluminados, "recuperados". En los casos en que eso no sucede, en que el espacio no genera riquezas inmobiliarias, ni comerciales, ni de tránsito - porque ya habíamos visto que "no lleva a ninguna parte" - la naturaleza es abandonada de toda regulación e inversión.

Una experiencia de acción colectiva en este contexto se desarrolló en el 2011, cuando la Red de Vecinos de San Vicente junto a otros actores de la zona, construyeron una plaza en la vera del río y realizaron una obra de arte en el puente Yapeyú - que cruza el río Suquía uniendo San Vicente y Yapeyú-. En este caso, la intervención actuaba sobre la ausencia estatal, sobre la degradación del espacio natural y de lo público.

Podríamos concluir, en este sentido, que para los actores hegemónicos —el Estado y las empresas desarrollistas - la naturaleza existe como pieza para la reproducción del capital o no existe. Sin embargo, para quienes habitan esos territorios, todo existe aunque no haya acumulación de capital. La refundación conflictiva de la que hablábamos adquiere, en este sentido, manifestaciones diferenciales que no por ello niegan su efectividad: en Alberdi la refundación del vínculo con el río Suquía requería el borramiento del espacio de jue-

\section{territarias 37}

refundación necesita del abandono de lo no-rentable y la Red de Vecinos intentó su transformación en espacio de uso vecinal.

\section{Tránsito turístico y tránsito de consumo. El capital "ordena"}

Además del rol de la naturaleza como elemento valorizador o desvalorizador del espacio urbano, agregamos una dimensión que ya Foucault (2011) en sus clases compiladas en el libro Seguridad, territorio y población desarrollaba: la íntima vinculación entre ciudades, seguridad y circulación. El problema de la circulación en sentido amplio implica para Foucault el "desplazamiento, intercambio, contacto, forma de dispersión y también de distribución" (p. 85). Afirma que el problema entonces es ¡cómo deben circular o no circular las cosas? Esto incluye cuerpos, mercancías, alimentos, ideas, enfermedades, etc.

En el mundo moderno, y particularmente en la vida urbana, el tránsito de personas y de mercancías define la dinámica general del consumo y abastecimiento de las industrias, las tendencias migratorias, la "seguridad" mundial y local, etc. En este sentido, mirar las dinámicas de circulación en la ciudad nos acerca a conocer más del orden de la vida urbana. Al interrogar las formas de ser/estar en las urbes y los encuentros/desencuentros que se proponen, las vías de tránsito son claves.

Venimos trabajando, además, una hipótesis: la circulación hoy se relaciona con experiencias subjetivas de velocidad, de no- 
implicamiento, de fugacidad, de circular y no detenerse.

Por ello, proponemos repetir el ejercicio de análisis y mirar ahora las vías de circulación y las experiencias posibles en el tránsito por los barrios propuestos. El caso de Alberdi, se presenta como una refundación turística del espacio. Esto propone un tránsito y circulación ordenado por la contemplación del turista: distante, desimplicado, observador de algo que le es anónimo, hermoso y ajeno. Pero además, y para muchos de los habitantes - no turistas- de complejos habitacionales de Alberdi, la circulación misma se desalienta por la construcción de entornos de encierro.

Un empresario define la zona diciendo: "Un millón de $\mathrm{m}^{2}$ de desarrollos en más de cincuenta y cinco torres, será la postal obligada de Córdoba" ("Iniciaron la obra de nueve mil millones de pesos", 2014, párr. 8). Caído en desuso el correo, una postal es una imagen para que se lleve el turista visitante; una especie de souvenir visual propio del capitalismo en su fase espectacular, en su operatoria en territorios neocoloniales (Scribano \& Boito, 2010). Estos empresarios, que se atribuyen el hecho y derecho de hacer la ciudad, la proyectan como imagen para $e l$ turista, pero no solo para el que viene a "vacacionar" sino que de alguna manera proponen y disponen formas de estar en la ciudad para sus habitantes: contribuyen a establecer un tipo de experiencia que tiene más que ver con pasar-tomar imágenes-mirar que con la posibilidad de la sociabilidad y apropiación del espacio (público/compartido) urbano.

De la misma manera podemos observar en las publicidades de las empresas las imágenes de esta privatización de la vida, vida puertas adentro, siempre protegida. La noción de entorno de clase y círculo de encierro que venimos trabajando, expresa su pertinencia:

La construcción de entorno/clasista/requiere de determinadas condiciones de realización, que fundamentalmente implican una modificación de la experiencia; es decir, y en primera instancia como hemos visto ya, una remodelación de espacio y tiempo como vectores que enmarcan y modelan aquello que vivenciamos. En cuanto al espacio, la condición inicial y fundacional es lo que Virilio denomina el vaciamiento de la calle. Para precisar: entornos enclasados requieren de la reorganización del alojamiento/ desalojamientos de las clases en el territorio urbano (Boito, 2013, p. 199).

Las imágenes con que se publicitan estos complejos habitacionales son expresivas de las experiencias a las que disponen: círculos de encierro voluntario, entornos "sin afuera", puesto que lo necesario y lo deseable está al alcance de la mano. Así, todas las opciones posibles, como narra uno de los spots, "estar, no estar, quedarme, irme" (Bestard \& Checchi, 2014a), quedan incluidas en la posibilidad de residir y consumir en un complejo cerrado, ya que, como se alegra el protagonista de otro de territarios 37

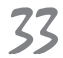


los spots, “¡afuera no hay nada!” (Bestard \& Checchi, 2014b).

En San Vicente el espectáculo para la experiencia del turista no resulta la fuerza ordenadora de los espacios y los cuerpos como lo es en Alberdi. No hay "belleza" para el mercado, ni objeto para publicitar en las enormes cartelerías. De hecho: no hay enormes cartelerías. En este sentido, San Vicente no pudo ser "refundado" de la manera en que lo fue Alberdi.

El desplazamiento de grupos sociales para la construcción de un entorno clasista se consuma, aunque con miras a sectores de menores recursos. En las ciudades del capital, todos tienen un espacio y un rol que ocupar. Si entendíamos que la segregación urbana se materializaba enclasando cuerpos en sectores delimitados del espacio; el espectáculo, el comercio, la circulación y la destrucción creativa se adecúan al nivel de reproducción del capital esperable para estos grupos humanos.

Se cuentan, en San Vicente, alrededor de veinticinco construcciones nuevas de edificios. La más alta, sobre la calle San Jerónimo, cuenta con solo ocho pisos. Los nuevos edificios en San Vicente están lejos de los complejos enrejados con spa y fachada natural o de antigüedad que Alberdi ofrece. Sintomáticamente, San Vicente se vio poblada de una publicidad llamativa en diciembre de 2015: una invasión de ofertas para demoliciones.

La calle San Jerónimo es la columna vertebral del barrio, pero también de la zona que involucra a diez barrios más y uno de los polos de pobreza más grandes.
Por allí transita el transporte urbano de pasajeros. Por allí se concentran los locales comerciales y administrativos, las ferias de ropa y los puestos de películas, verduras y tortillas. Por esa calle están las plazas públicas y, por todo ello, circula la mayoría de las personas. Para ellas, el capital propone el consumo de mercancias diarias, ofertas de camas, bolsas de golosinas, sillas caño, ropa de bebé, zapatillas y electrodomésticos. Un consumo a baja escala de vivienda y de vidrieras. Es este consumo el que ordena la circulación por la zona: fugaz, desencontrada, individual, que dirige las miradas hacia los márgenes del espacio público marcado por las vidrieras: todos miran para afuera, a donde están los objetos deseados en exposición, no hacia adentro, donde están la otras personas, los vecinos.

De lo que antes era un polo de pequeñas industrias, San Vicente se tornó un polo comercial con emprendimientos inmobiliarios de baja gama. Esos emprendimientos junto a la valorización comercial y a la inversión pública y privada en ciertas áreas del barrio, lo sitúan dentro y no fuera de las tendencias contemporáneas de reordenamiento urbano.

El embellecimiento, la "puesta en valor", la "recuperación" del espacio en la ciudad, han implicado siempre restricción y control sobre la circulación. El sector privado avanza sobre los espacios públicos como espacios de consumo. Avanza también sobre el patrimonio tangible, demoliendo, ocultando, transformando edificaciones de valor histórico y arquitectónico. Es un leitmotiv de este cruento proceso de con-

Cecilia Michelazzo, Katrina Salguero Myers 
formación de ciudades como espectáculo turístico y como círculo de consumo la inclusión de proyectos para la creación de "centros culturales", "museos" o "centros comerciales" con toque de antigüedad. Como explica María Carman (2011b), "se reivindica el patrimonio para todos pero se altera la naturaleza social de sus habitantes" (p. 266). Se trata del más clásico -y burdo- ejercicio de trabajo ideológico: se propone como universal lo que en la práctica implica la posibilidad para algunos particulares — siempre determinados por la posición de clase en la estructura social-

\section{Conclusiones sobre el capitalismo en las ciudades: el desalojo, la refundación, la ganancia}

Como habitantes de las ciudades, nada de lo que analizamos desde el rol de cientistas nos resulta del todo ajeno. Ni los cuerpos regulados ordenados, ni las expropiaciones de tiempo y espacio, ni las experiencias de lo masivo y lo anónimo, ni los circuitos cerrados de circulación, ni el refugio en la naturaleza embellecida, ni la huida de la naturaleza abandonada.

Al decir de Harvey (2012), son las ideas que emergen en las calles y los barrios de las doloridas urbes las que dibujan los trazos más gruesos sobre qué son y deberían ser nuestras ciudades y, sobre todo, la vida en las ciudades ${ }^{15}$. No sería, así, la genialidad de algún autor sino la vida en la ciudad y los intereses contrapuestos los que definen sus batallas, los que marcan lo que merece ser defendido y abandonado, lo que puede ser destruido o transformado. Todo eso es, para el autor inglés, "lo común".

Las ciudades son, así, una producción común y necesariamente social. Emergen, en ellas, actores de clase que materializan la disputa en el presente. Tal como hace una década en Córdoba esa conflictividad estaba protagonizada por el gobierno provincial y las villas desalojadas; hoy están en el centro de la disputa los grupos empresariales desarrollistas y los grupos de vecinos de barrios "tradicionales" como San Vicente y Alberdi. El objeto de la contienda parece ser la vida misma, comprendida como modo de vida, y regulada por las condiciones urbanas de reproducción social (vivienda, servicios, espacios verdes, circulación, cultura, identidad).

Julieta Capdevielle (2013) reconstruye cómo los empresarios se relatan así mismos y muestra, a través de entrevistas en profundidad a los desarrollistas urbanos, cómo "las empresas se adjudican explícitamente su (legítima) capacidad de intervenir en las decisiones públicas sobre el uso del espacio sustentado en un conocimiento específico del que el resto de la población está desprovisto" (Capdevielle, 2013, p. 12). Asimismo, la investigadora analiza cómo las empresas más grandes - las que manejan más recursos y realizan proyectos de mayor envergadura, las que acceden a los "convenios urbanísticos" para construir más allá de la normativa - conciben su accionar como "hacer ciudad", "transformar ciudad", "reformar la ciudad", "generar un punto de inflexión en la trama urbana", etc. ${ }^{16}$. Decíamos que estas transformacio-
15 "And if various movements of an analogouskind can be found elsewhere, it is not simply out of some fealty to Lefebvre's ideas but precisely because Lefebrre'sideas, like theirs, have primarily arisen out of the streets and neighborhoods of ailing cities” (Harvey, 2012, p. XII).

${ }^{16}$ Esta idea se plasma también en las publicidades de las empresas y en los videos institucionales de la cámara empresarial que las agrupa (CEDUC), como hemos analizado en Espoz, Michelazzo \& Sorribas (2010) Es particularmente significativa una $p u$ blicidad de GAMA S.A., donde lo que se muestra es un recorrido por un paisaje en apariencia desierto, en medio del cual la empresa construye y funda "de la nada" una ciudad completa de torres.

\section{territarias 37}

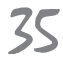


nes intentan refundar los espacios: sancionar la llegada de algo nuevo, que no estaba, y así construir con lo viejo un "nuevo tiempo en un nuevo espacio".

Sin embargo, la producción y la apropiación de lo común, como hemos visto, se presenta como parte de la lucha de clases. Por eso, reconocimos que en las experiencias de resistencia nombradas de la Multisectorial Defendamos Alberdi y de la Red de Vecinos de San Vicente, de lo que se trata es de con-mover el marco formal (ideológico) de los derechos individuales/ privados, subvertir la lógica de derecho anónimo y genérico, del valor cambio de las cosas; instituyendo una mirada del espacio vital en su valor de uso, del tiempo como detenimiento, y lo común como todo aquello que puede ser producido como tal.

En esta línea, la pregunta por "los comunes" en Harvey (2012) nos devuelve a la crítica radical de la revoluciones burguesas que hiciera Marx en La cuestión judia: "Ninguno de los llamados derechos del hombre sobrepasa, pues, al hombre egoísta, al hombre tal como es, miembro de la sociedad civil, al individuo cerrado sobre sí mismo, reducido a su interés privado y a su arbitrio particular, separado de la comunidad" (Marx, 2005, p. 40). Estas impugnaciones a la semantización de la ciudad y los derechos, como tendencias existentes en el espacio/tiempo presente, pueden actualizarse a partir de identificar el carácter de relación - no de sustancia- del capitalismo en tanto lógica dominante que marca cuerpos y territorios.
Es en la tensión entre valor de uso y valor de cambio de la tierra, la vivienda, la ciudad y no en la categorización de inquilinos o propietarios o grupos medios o bajos, donde reconocemos la lucha de clases en y por la ciudad. Es, de este modo, en la relación conflictiva entre la reproducción vital y su contradicción con la acumulación de capital y el embellecimiento estratégico, donde radica la disputa. La coyuntura económico-política y los múltiples factores que confluyeron en la última década y media para trazar la sobreacumulación; la reproducción ampliada del capital en las ciudades a través de la construcción de viviendas suntuarias para sectores de altos ingresos; los desalojos que se necesitaron para realizar tales construcciones y las resistencias dispersas que se generaron en aquel contexto; los mercados locales para grupos diferenciales; la trama de identidades y lógicas de acción y organización barriales; son todas líneas de fuerza que bacen la ciudad hoy. Es dentro de esas relaciones y atravesada desigualmente por el conflicto capital-trabajo en que la apropiacióndesposesión-significación-destrucción de los comunes se dirime.

Como suele sucedernos en la búsqueda de la comprensión crítica del mundo, volvemos a Marx para pensar los límites de lo pensable y volvemos también a su explicación del funcionamiento del capital: aquel recorrido que partía de un D-M (dinero- mercancía) inicial; al que luego se le invertía una mercancía especial llamada FT (fuerza de trabajo) junto a la Mp (materia prima); para llegar a tener un D'-M' mayor

Cecilia Michelazzo, Katrina Salguero Myers 
a los anteriores. Y de ahí, la apropiación de la plusvalía y la explotación como contracaras del proceso en términos clasistas.

En la diacronía de lo social urbano en Córdoba, podemos pensar en este circuito partiendo de los desalojos compulsivos que garantizaron aquella mercancía/tierra originaria; en la fuerza de trabajo invertida en las refundaciones urbanas; y en la "plusvalía urbana" de la que se apropian ciertas clases y de la que otras son desposeídas. Sin pretender ser esquemáticas ni ignorar las complejidades, el circuito del capital propuesto por Marx sigue iluminando aristas nuevas para mirar objetos contemporáneos, al menos conmoviendo nuestros marcos de aprehensión de la realidad: nos recuerda que la primera mercancía-dinero (D-M) del ciclo surge de una desposesión (Harvey) o una acumulación originaria (Marx). No con esto decimos originaria como arjé (origen, inicio), sino que el ciclo es iniciado una y otra vez, y siempre supone la existencia de una propiedad privada mercantilizada que fue apropiada anteriormente - sea por la fuerza como en un desalojo, sea por un acuerdo como en una compra-. El circuito del capital nos recuerda, también, que la refundación urbana no se efectúa sin trabajadores y trabajadoras, sin una clase que vende su fuerza de trabajo (FT) para reproducir sus condiciones de vida cobrando un salario. Esa misma fuerza de trabajo es la que hace que el dinero-mercancía resultante tenga más valor. Marx nos recuerda, así, que no hay alquimia en la reproducción ampliada del capital más que como operación ideológica de ocultamiento. No hay magia alguna. Hay trabajo invertido y trabajadores, hay capitales diferenciales, poder y cuerpos puestos a funcionar en pos de un objetivo.

Así, la denominada sin vueltas "plusvalía urbana" no esconde nada, sino que se manifiesta pornográficamente: por ejemplo, cuando se construye un centro cultural en un lugar que no debía ser demolido según normativas urbanas. Los empresarios lo construyen como forma de pago, como "multa" por haber destruido parte del patrimonio común en Alberdi. Esa porción de la ganancia - pagada al Estado por excederse de la normativa ${ }^{17}$ - en el mismo acto aumenta la ganancia: se hace del espacio un nuevo negocio.

En esta línea, entendemos que las disputas por la ciudad, las apropiaciones de la naturaleza y los derechos de fundación y refundación de lo urbano, así como los conflictos -más explícitos o más intersticiales - que emergen por la voluntad de disputar las capacidades de reproducir la vida - en sus dimensiones materiales, significantes y sensibles- no deben ser reducidas o encorsetadas a una lectura marxista de la lucha de clases; pero difícilmente pueden leerse prescindiendo de ella. Es en el seno del sistema capitalista periférico, y por ello en el seno de una configuración clasista de lo histórico-social, que estos fenómenos emergen.

Nos queda la tarea de avanzar en la construcción de una vertiente posible para una crítica radical al presente: develando en lo que se muestra cosificado y concluso, fundado y natural; aquello ha sido produ-
${ }^{17}$ De esto tratan los Convenios urbanisticos, instrumento legal que permite negociar al Municipio con las empresas constructoras para realizar obras por fuera de la normativa a cambio de una "plusvalía urbana" que la empresa paga al Estado, generalmente en forma de obras. Así termina ocurriendo que, en general, las obras de retribución al Estado benefician en realidad a las propias empresas aumentando aún más sus ganancias, mejorando la accesibilidad vial de lasedificaciones, o, como en este caso, otorgando un plus de valor "cultural" a susobras.

territarias 37

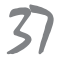


cido por el trabajo y la lucha. Trabajo que implica también la labor de las ciencias y los esfuerzos transdisciplinares por comprender cómo se construyen las dimensiones materiales, significantes y sensibles de la vida. Cómo, por ejemplo, de los ideales modernos "fundacionales" evocados al empezar este escrito, referenciados a la Revolución Francesa de 1789, la "fraternidad" ha sido la hermana olvidada.

\section{Referencias}

Benjamin, W. (1999). Poesía y capitalismo: Iluminaciones II. Madrid: Taurus.

Bestard, D. \& Checchi, P. (2014a). Sola (Video). Recuperado de https://www.youtube.com/watch?v=2dQ37qOOAWQ

Bestard, D. \& Checchi, P. (2014b). Risas (Video). Recuperado de https://www. youtube.com/watch?v=J8aU_3tSPNM

Boito, M. E. (2013). La noción de entorno clasista como encuadre de la experiencia en contextos de socio-segregación. En F. Nievas (Comp.), Mosaico de Sentidos (pp. 191-206) Buenos Aires: Estudios Sociológicos Editora.

Boito, M. E. \& Espoz, M. B. (Comp.). (2014a). Urbanismo estratégico y separación clasista. Instantáneas de la ciudad en conflicto. Rosario: De Puño y Letra.

Boito, M. E. \& Espoz, M. B. (noviembre, 2014b). Embellecimiento estratégico de la ciudad: exploración sobre dos espacios en disputa en barrio Alberdi (El Bordo y La Piojera). Ponencia presen-

\section{territarias 37}

Territoriales, Universidad Nacional de Córdoba, Córdoba.

Boito, M. E. \& Michelazzo, C. (2014). Córdoba en pedazos. Habitar/circular en contextos sociosegregados. Estudios Sociales Contemporáneos, (10), 45-58.

Capdevielle, J. (noviembre, 2013). Cambios y continuidades de los grupos 'desarrollistas' y su incidencia en la ciudad de Córdoba, Argentina. Ponencia presentada en las VII Jornadas Santiago Wallace de Investigación en Antropología Social, Universidad de Buenos Aires, Buenos Aires.

Capdevielle, J. (2014). Espacio urbano y desigualdades: las políticas públicas y privadas en la ciudad de Córdoba, Argentina. Cuadernos Geográficos, 53(2). Recuperado de http://revistaseug.ugr. es/index.php/cuadgeo/rt/printerFriendly/2224/3062

Carman, M. (2011a). Las trampas de la naturaleza. Medio ambiente y segregación en Buenos Aires. Buenos Aires: Fondo de Cultura Económica.

Carman, M. (2011b). El proceso de ennoblecimiento y la salida negociada de los innobles en Buenos Aires. Cadernos Metrópole, 3(2), 257-278.

D’Amico, D. (2008). Redes socio-politicas y desempeño organizacional en asociaciones vecinales de los barrios populares de la ciudad de Córdoba, Argentina. (Tesis de Maestría sin publicar). Universidad Católica de Córdoba, Córdoba, Argentina.

Derrida, J. (1997). Fuerza de ley. El "fundamento místico de la autoridad". Madrid: Tecnos.

Cecilia Michelazzo, Katrina Salguero Myers 
Espoz, M.B., Michelazzo, C. \& Sorribas, P. (2010). Narrativas en conflicto sobre una ciudad socio-segregada. Una descripción de las mediaciones que la visibilizan. En A. Scribano \& E. Boito (Comps.), El Purgatorio que no fue: Acciones profanas entre la esperanza y la soportabilidad (pp. 83-106). Buenos Aires: CICCUS.

Foucault, M. (2011). Seguridad, territorio, población: Curso en el College de France: 1977-1978. Buenos Aires: Fondo de Cultura Económica.

Harvey, D. (2004). El nuevo imperialismo: acumulación por desposesión. Madrid: Akal.

Harvey, D. (2008). El derecho a la ciudad. New Left Review, (53), 23-39.

Harvey, D. (2012). Rebel cities. From the right to the city to the urban revolution. Nueva York: Verso.

Iniciaron la obra de nueve mil millones de pesos ( 18 de diciembre de 2014). Comercio y justicia. Recuperado de http://comercioyjusticia.info/blog/negocios/ iniciaron-la-obra-que-mueve-mil-millones-de-pesos/

Janoshka, M. \& Sequera J. (2014). Procesos de gentrificación y desplazamiento en América Latina una perspectiva comparativista. En J. J. Michelini (Ed.), Desafíos metropolitanos. Un diálogo entre Europa y América Latina (pp. 82104). Madrid: Catarata. Recuperado de http://contested-cities.net/wp-content/uploads/2014/07/2014CC_Janoschka_Sequera_Desplazamiento_ AL.pdf
Marengo, C. (2013). Extensión urbana e intervenciones habitacionales. El caso de la ciudad de Córdoba (Argentina). Cuadernos de Vivienda y Urbanismo, 6(12). Recuperado de http://revistas. javeriana.edu.co/index.php/cvyu/article/view/7037/5596

Marx, K. (2005). La cuestión judia. Buenos Aires: Nuestra América.

Molinatti, F. (2013). Cambios en los patrones de segregación residencial en la ciudad de Córdoba. Años 1991, 2001 y 2008. (Tesis de Maestría sin publicar). Universidad Nacional de Córdoba, Córdoba, Argentina.

Peralta, C. \& Liborio, M. (2014). Redistribución poblacional en la ciudad de córdoba entre los períodos intercensales 1991-2001/2001-2008. Evaluación de los procesos de dispersión, densificación, gentrificación y renovación. Vivienda y Ciudad, 1, 99-113.

Salguero, K. (2015). Segregación urbana y reproducción del capital. El caso de la ciudad de Córdoba (2003-2013), sus transformaciones físicas y las experiencias sociales posibles. En M. E. Boito (Comp.), Lo popular en la estructura de la experiencia contemporánea (pp. 201-228). Buenos Aires: El Colectivo. Scribano, A. \& Boito, M. E. (2010). La ciudad sitiada: una reflexión sobre imágenes que expresan el carácter neocolonial de la ciudad (Córdoba, 2010). Actuel Marx. Intervenciones, (9), 239-259.

Sennett, R. (2003). Carne y piedra. El cuerpo y la ciudad en la civilización occidental. Madrid: Alianza Editorial. territarias 37 
Thomasz, A. G. (2014). El derecho a la ciudad hoy, ¿cómo se construye? En M. R. Millán \& W. F. Brites (Comps. \& Eds.), Ciudadesvivas. Imaginaciones sobre el territorio (pp. 124-157). Posadas: Universidad Nacional de Misiones \& CONICET.
Vecinos reclaman contra la demolición de una cancha (3 de junio de 2015). CBA24N. Recuperado de http://www.cba24n. com.ar/content/vecinos-reclamancontra-la-demolicion-de-una-cancha 